\title{
Analisis Manajemen Tatalaksana Kanker Ginekologi di RSUP Sanglah di Era Pandemi COVID-19
}

\author{
I Gde Sastra Winata, Ngakan Ketut Darmawan, I Nyoman Bayu Mahendra \\ Bagian/SMF Obstetri dan Ginekologi FK UNUD/RSUP Sanglah Denpasar \\ Korepondensi: Ngakan Ketut Darmawan, Email: wawandarmawan291289@gmail.com
}

\begin{abstract}
Abstrak
Pandemi COVID-19 memberikan tantangan tersendiri dalam penanganan kanker, khususnya kanker ginekologi. Kondisi pasien penderita kanker yang telah mengalami immunocompromised baik karena penyakitnya maupun efek samping dari obat-obatan yang diberikan, berpotensi meningkatkan risiko pasien kanker untuk mengalami infeksi COVID-19 berat. Penatalaksanaan utama dari kanker yang bertonggak pada tiga poros yaitu operasi, kemoterapi, dan radioterapi perlu dilakukan adaptasi demi meningkatkan angka survival rate pada pasien.
\end{abstract}

Kata kunci : COVID-19; kemoterapi; operatif; radioterapi; kanker ginekologi

\section{Management of Gynecological Cancers in the COVID-19 Era: a Persepctive from Sanglah General Hospital}

\begin{abstract}
The COVID-19 pandemic as challenges in dealing with cancer, especially gynaecological cancer. The condition of cancer patients who have experienced immunocompromised due to both the disease and the side effects of the drugs increases the risk of cancer patients to experience severe COVID-19 infection. The management of cancer consists of three axes; surgery, chemotherapy, and radiotherapy, and needs to be adapted to increase patient survival.
\end{abstract}

Key word: COVID-19; chemotherapy; operative; radiotherapy; gynaecological cancer 


\section{Pendahuluan}

Sebuah wabah penyakit koronavirus-2019 (COVID-19) terjadi pada akhir tahun 2019 yang berawal dari kota Wuhan, Cina dan menyebar secara cepat ke seluruh dunia. Berdasarkan data dari Komite Penanganan COVID-19 dan Pemulihan Ekonomi Nasional, kasus konfirmasi positif COVID-19 di Indonesia sudah menembus angka 1 juta hingga akhir Januari 2021.,2,3"'ti tle":"Characteristics of and Important Lessons From the Coronavirus Disease 2019 (COVID-19 World Health Organization (WHO) mendeklarasikan COVID-19 sebagai kegawatdaruratan kesehatan masyarakat yang memerlukan perhatian khusus, tak terkecuali bidang ginekologi.

Angka statistik di RSUP Sanglah sekitar 476 pasien dengan kanker ginekologi, dan dalam konteks pandemi COVID-19 saat ini dan keterbatasan layanan resusitasi. Selama 2-3 bulan ke depan, hal yang harus diperhatikan tidak hanya terpaku pada penanganan tetapi juga mengurangi risiko infeksi pada pasien kanker. Untuk mengurangi risiko infeksi, dua prioritas penting: membatasi situasi berisiko tinggi seperti pembedahan, kemoterapi, radioterapi; dan untuk membatasi kontak pasien dengan petugas perawatan kesehatan dan, khususnya dengan tempat perawatan. ${ }^{4}$

Pasien kanker lebih berisiko untuk menderita infeksi berat. Hal ini diperberat dengan penggunaan regimen kemoterapi dan obat antikanker lainnya yang berdampak pada kondisi immunocompromised terhadap pasien kanker yang menyebabkan pasien lebih rentan terhadap infeksi, baik infeksi virus maupun infeksi penyakit lainnya. ${ }^{4}$

Sebuah penelitian yang dilakukan di sebuah rumah sakit tingkat tersier di Nigeria Tenggara dari tahun 20002010, mengungkapkan bahwa tantangan pengobatan kanker ginekologi bervariasi mulai dari deteksi dini yang terlambat, ketidakpatuhan dalam menjalani terapi, kurangnya penggunaan obat-obatan sitotoksik yang lebih mutakhir, hasil yang kurang baik dari prosedur operasi, dan kurangnya fasilitas radioterapi fungsional. ${ }^{5} \mathrm{Hal}$ ini bisa menjadi perhatian dalam usaha untuk meningkatkan angka survival rate dari penderita kanker ginekologi selama era pandemi di tengahtengah keterbatasan terapi saat ini.

Di antara segala permasalahan yang ada, tulisan ini secara khusus akan menyajikan penanganan COVID-19 berkaitan dengan penyakit kanker, terutama kanker ginekologi. Tanpa adanya pandemi COVID-19, kanker sendiri merupakan salah satu masalah besar yang membebani kesehatan manusia. Hal yang menjadikan friksi antara kanker dan COVID-19 adalah penatalaksanaan kanker. Manajemen utama kanker berporos pada tiga metode, yaitu : operasi, kemoterapi, dan radioterapi. Ketiga metode tersebut memberikan beban tersendiri terhadap sistem imunitas tubuh. Pertimbangan untuk melakukan manajemen pada kanker ginekologi memerlukan strategi khusus pada saat pandemi ini. ${ }^{6}$

\section{Pembahasan \\ Kemoterapi}

Dalam pemilihan regimen kemoterapi, direkomendasikan untuk memilih regimen yang memerlukan kunjungan terapi paling sedikit seperti regimen paclitaxel/carboplatin 3 minggu. Perlu adanya pertimbangan untuk menghindari atau membatasi dosis tinggi, intraperitoneal, dan hyperthermic intraperitoneal chemotherapy (HIPEC). Halhal yang perlu diperhatikan sebelum, selama, dan sesudah kemoterapi ada pada tabel 1 .

Tantangan pengobatan kemoterapi selama pandemi, khususnya di negara berkembang meliputi terbatasnya persediaan obat-obatan kemoterapi karena faktor terganggunya proses produksi dan rantai pasokan obat-obatan. Selain itu, 


\section{Tabel 1 Pertimbangan Sebelum, Selama, dan Sesudah Kemoterapi pada Pasien Kanker Yang Perlu Dilakukan di Era Pandemi. ${ }^{7}$}

\begin{tabular}{|c|c|}
\hline Sebelum kemoterapi & $\begin{array}{l}\text { Pertimbangkan tujuan terapi: Terapi kuratif lini pertama harus diprioritaskan. Terapi } \\
\text { pemeliharaan (maintenance) harus dievaluasi untuk menilai manfaat survival pada } \\
\text { pasien dan terapi paliatif perlu dilakukan untuk mengurangi gejala penyakit kanker } \\
\text { yang tak terkontrol. } \\
\text { Pasien sebaiknya tidak dirawat di rumah sakit yang menjadi pusat rujukan pasien CO- } \\
\text { VID-19. } \\
\text { Perlu mempertimbangkan administrasi dari regimen kemoterapi jika tempat tinggal } \\
\text { pasien jauh dari fasilitas kesehatan atau jika pasien ada rencana untuk mengunjungi } \\
\text { area rawan dengan kasus COVID-19 tinggi. } \\
\text { Usahakan untuk mengurangi frekuensi infus kemoterapi dan infus mingguan. } \\
\text { Perlu pertimbangan khusus untuk terapi single agent atau menunda kemoterapi pada } \\
\text { pasien }>65 \text { tahun, pasien dengan penyakit komorbid (DM, PPOK, dan penyakit kar- } \\
\text { diovaskuler) atau status ECOG } \geq 2 \text {. } \\
\text { Pertimbangkan penggunaan terapi oral daripada terapi berbasis infus jika memung- } \\
\text { kinkan. Namun perlu diperhatikan juga bahwa beberapa regimen oral bersifat lebih } \\
\text { toksik daripada regimen infus. } \\
\text { Usahakan untuk rawat jalan pasien kemoterapi jika memungkinkan. } \\
\text { Screening semua pasien untuk gejala-gejala COVID-19 dan pengukuran suhu }<37,5 \\
{ }^{\circ} \text { C sebelum pengobatan dan testing sebelum menjalani kemoterapi. }\end{array}$ \\
\hline Selama kemoterapi & $\begin{array}{l}\text { Mengintegrasikan terapi dengan telemedicine untuk mengurangi frekuensi kunjungan } \\
\text { pasien ke evaluasi di faskes dan pasien bisa langsung ke pusat kemoterapi untuk men- } \\
\text { jalani pengobatan. } \\
\text { Pertimbangkan untuk rawat jalan untuk tatalaksana demam neutropenik jika klinis } \\
\text { pasien stabil dengan moxifloxacin } 400 \mathrm{mg} \text { oral satu kali sehari atau ciprofloxacin 500- } \\
750 \mathrm{mg} \text { oral dua kali sehari dan Augmentin } 875 \mathrm{mg} \text { oral dua kali sehari. Follow-up } \\
\text { bisa dilakukan menggunakan kontak telepon minimal selama } 3 \text { hari untuk memastikan } \\
\text { kondisi klinis pasien. }\end{array}$ \\
\hline Sesudah kemoterapi & $\begin{array}{l}\text { Menunda foto radiologi kecuali untuk penanganan gawat darurat atau kritis. } \\
\text { Pastikan tujuan dari layanan kesehatan dengan mendiskusikannya bersama pasien } \\
\text { lebih diprioritaskan sebelum atau sesaat setelah rawat inap, komunikasi menggunakan } \\
\text { telemedicine atau telepon bisa digunakan. } \\
\text { Memperpanjang interval port flush rutin menjadi 8-12 minggu. }\end{array}$ \\
\hline
\end{tabular}

timbul upaya untuk menghindari kondisi immunocompromised pada pasien agar tidak mengalami infeksi berat sehingga pasien tidak mendapatkan terapi yang seharusnya. ${ }^{8}$

Rekomendasi untuk lini pertama regimen kemoterapi menurut The Society of Gynecologic Oncology terbagi berdasarkan stage malignansi pada pasien. Penjabaran lebih detail ada di tabel 2 dan tabel 3. 
Tabel 2 Rekomendasi Lini Pertama Regimen Kemoterapi pada Masing-Masing Jenis Kanker Ginekologi Early-Stage Selama Pandemi COVID-19. ${ }^{7}$

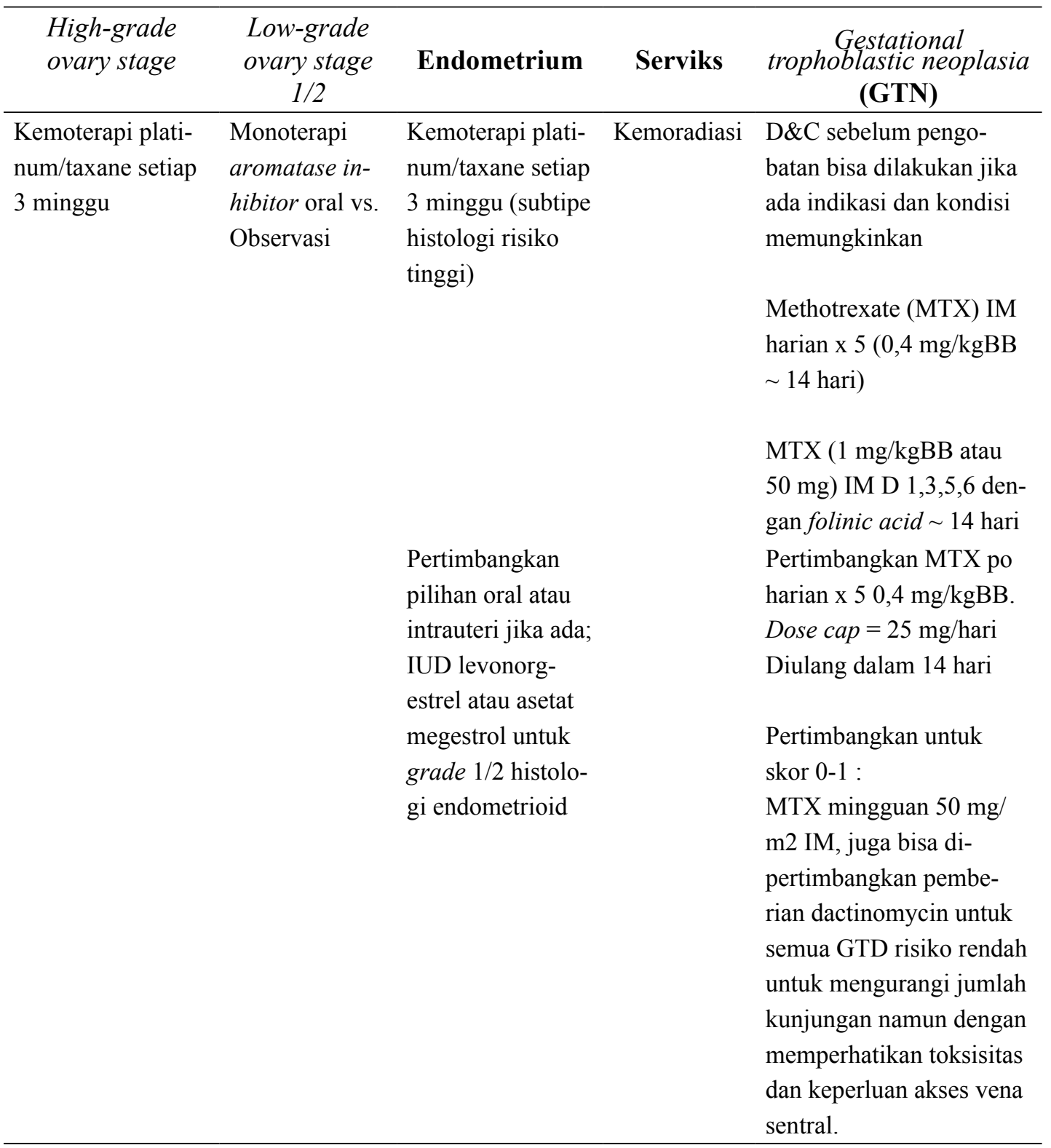


Tabel 3. Rekomendasi lini pertama regimen kemoterapi pada masing-masing jenis kanker ginekologi advanced-stage selama pandemi COVID-19. ${ }^{7}$

\begin{tabular}{|c|c|c|c|c|c|}
\hline $\begin{array}{l}\text { High-grade } \\
\text { ovary stage }\end{array}$ & $\begin{array}{c}\text { Low-grade } \\
\text { ovary stage } \\
1 / 2\end{array}$ & Endometrium & Serviks & Vulva & $\begin{array}{c}\text { Gestational } \\
\text { trophoblastic } \\
\text { neoplasia } \\
\text { (GTN) }\end{array}$ \\
\hline
\end{tabular}

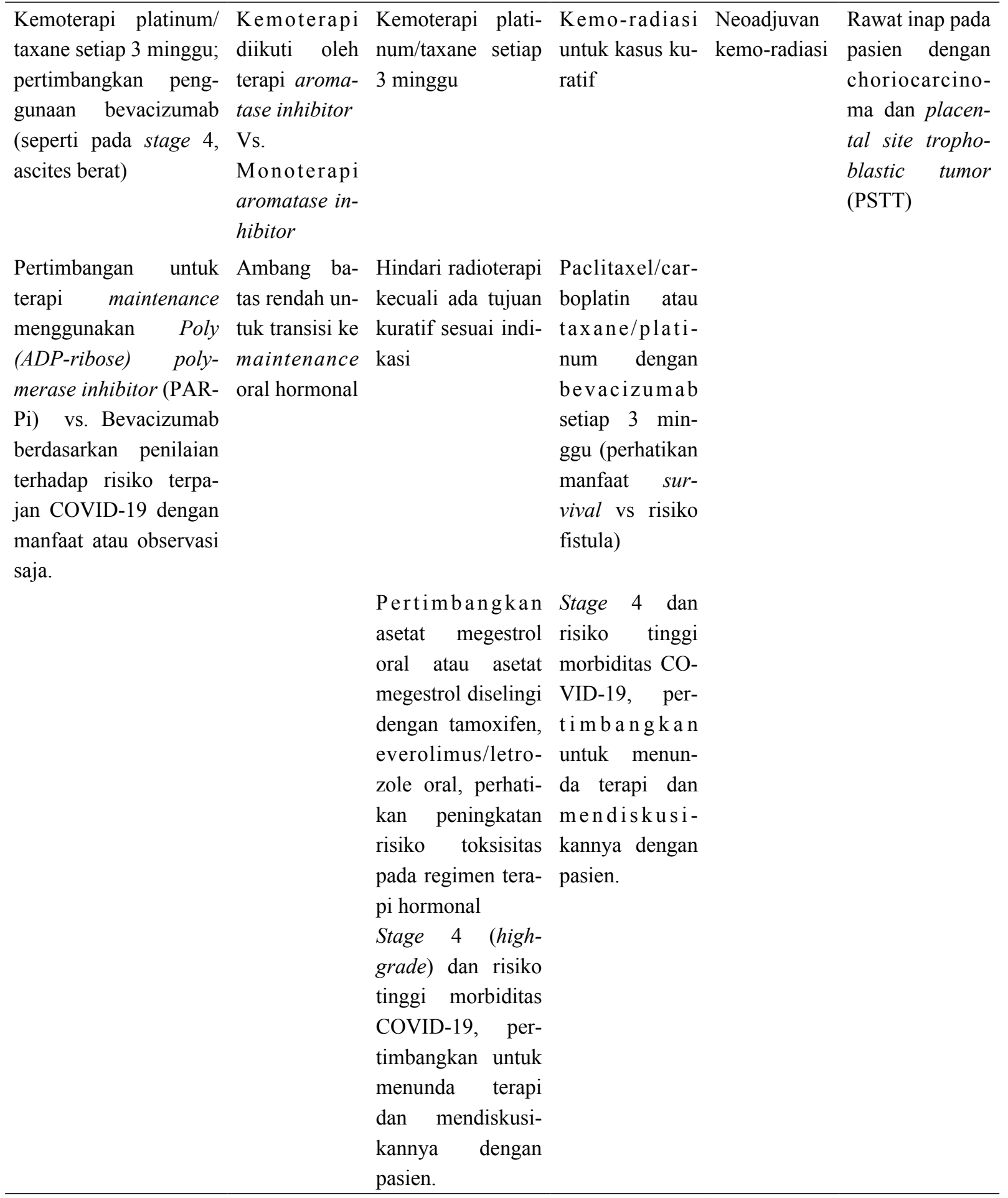




\section{Radioterapi \\ Kanker Serviks}

Pada pasien post-operatif, radioterapi pada pasien kanker serviks bisa ditunda hingga 8-12 minggu bergantung dari kondisi klinis. Pada pasien yang tidak bisa menerima terapi sistemik dan membutuhkan radioterapi eksternal, radioterapi akselerasi bisa diberikan 6 hari tiap minggu. Semua pengobatan sudah harus selesai dalam 8 minggu dengan dosis yang sesuai dan penundaan tidak direkomendasikan karena akan memengaruhi angka survival. ${ }^{8}$

\section{Kanker Endometrium}

Pada pasien yang tidak dapat dilakukan operasi dan simptomatik, radioterapi dengan atau tanpa kemoterapi perlu diberikan secepatnya. Untuk pasien dengan histologi endometrioid, terapi hormonal bisa digunakan untuk menunda inisiasi radioterapi. Brakiterapi lebih disarankan daripada stereotactic body radiation therapy (SBRT) untuk mengurangi risiko toksisitas. ${ }^{8}$

Pada pasien post-operatif, radioterapi adjuvan bisa diberikan dengan durasi penundaan selama 6-8 minggu setelah operasi bergantung dari kondisi klinis. Regimen brakiterapi lebih direkomendasikan untuk mengurangi jumlah kunjungan ke rumah sakit. $^{8}$

\section{Kanker Ovarium}

Pasien yang sudah menjalani operasi dan kemoterapi sebelumnya, bisa melibatkan radioterapi sebagai terapi adjuvan. ${ }^{8}$

\section{Kanker Vagina}

Pasien kanker vagina dengan penyakit yang masih baru, direkomendasikan untuk menerima radioterapi definitif dengan atau tanpa kemoterapi dan harus diterapi secepatnya. Untuk radioterapi dengan external beam, boost perlu dilakukan menggunakan simultaneous integrated boost (SIB). Pada pasien post-operatif, radioterapi adjuvan dapat ditunda selama 6-8 minggu setelah operasi bergantung dari kondisi klinis. ${ }^{8}$

\section{Kanker Vulva}

Pasien kanker vulva dengan penyakit yang masih baru, direkomendasikan untuk menerima radioterapi definitif dengan atau tanpa kemoterapi dan harus diterapi secepatnya. Pada pasien post-operatif, radioterapi adjuvan dapat ditunda selama 6-8 minggu setelah operasi bergantung dari kondisi klinis. Pasien-pasien post-operatif yang ditemukan memiliki keterlibatan nodul pada saat operasi, diperlukan inisiasi radioterapi dengan cepat. ${ }^{8}$

\section{Operatif \\ Kanker Serviks}

Lesipra-invasifserviks: Menurutrekomendasi American Society for Colposcopy and Cervical Pathology (ASCCP), individu dengan tes skrining kanker serviks tingkat rendah boleh mengalami penundaan evaluasi diagnostik selama 6-12 bulan. Pasien dengan tes skrining serviks tingkat tinggi harus memiliki evaluasi diagnostik yang dijadwalkan dalam waktu 3 bulan. ${ }^{9}$

Kanker serviks stadium awal: Dalam keadaan di mana operasi onkologis masih diperbolehkan, dianjurkan untuk melanjutkan dengan perawatan standar. Namun, jika akses untuk tindakan operasi terbatas, langkah-langkah ini dapat dipertimbangkan. Memastikan bahwa penyakit terlokalisasi dengan studi pencitraan, seperti CT scan. Jika demikian, pertimbangan untuk menunda prosedur yang mungkin dianggap berisiko tinggi untuk waktu operasi yang lama, atau potensi intraoperatif. dan / atau komplikasi 
pasca operasi, seperti trakelektomi radikal atau histerektomi radikal, untuk jangka waktu 6-8 minggu, atau sampai krisis teratasi. ${ }^{9}$

\section{Kanker Endometrium}

Pasien berisiko rendah: Pasien dengan penyakit tingkat 1 dapat dipertimbangkan untuk manajemen konservatif dengan opsi non-bedah, termasuk terapi hormonal sistemik atau alat kontrasepsi. ${ }^{9}$ Pasien berisiko tinggi: Pasien dengan penyakit berisiko tinggi (derajat 2 atau 3 atau histologi berisiko tinggi) harus dipertimbangkan untuk histerektomi sederhana dan bilateral salpingooophorectomy tunggal \pm sentinel lymph nodes, jika tersedia dan memungkinkan, dan / atau berdasarkan manajemen pasca operasi tentang faktor risiko uterus. Risiko operasi laparoskopi terkait pneumoperitoneum dalam scenario COVID-19 harus dipertimbangkan dengan risiko laparotomi. ${ }^{9}$

\section{Kanker Ovarium}

Pada dugaan penyakit stadium dini, pertimbangan beberapa faktor, seperti usia dan riwayat keluarga kanker payudara / ovarium, pemeriksaan fisik, dan evaluasi radiologis menyeluruh dengan USG panggul dengan color Doppler, MRI, dan / atau penanda serum, seperti CA125 dan HE4, untuk menilai risiko keganasan pada massa adneksa. $^{9}$ Pada pasien dengan penyakit stadium lanjut, pertimbangan biopsi jaringan untuk memastikan diagnosis penyakit dan dilanjutkan dengan kemoterapi neo-adjuvan sampai krisis teratasi dan pertimbangan pembedahan di lain waktu. ${ }^{9}$

\section{Pertimbangan Era Pandemi COVID-19}

Pada Maret 2020, rekomendasi dikeluarkan oleh American College of Surgeons (ACS), U.S. Surgeon General, dan beberapa perkumpulan profesional medis dan bedah untuk menunda intervensi bedah elektif. Rekomendasi ini didasarkan pada keinginan untuk melindungi pasien dan tenaga medis dari komplikasi terkait COVID-19 dan melestarikan sumber daya rumah sakit untuk meningkatkan daya tampung pasien COVID-19. Pada akhirnya, pandemi telah menantang kemampuan tenaga medis untuk memberikan perawatan tepat waktu bagi pasien, termasuk pasien dengan kanker ginekologi. Pasien dengan keganasan ginekologi sering membutuhkan intervensi bedah sepanjang rangkaian perawatan kanker mereka, yang telah terganggu selama masa ini. ${ }^{10}$

Pada bulan Desember 2020 - Februari 2021, terdapat 31 pasien kemoterapi seri 1 yang baru, jangka waktu yang dibutuhkan untuk mendapatkan kemoterapi seri 1 sejak didiagnosis kanker serviks berkisar antara 37 - 53 hari, dengan rerata 37 hari telah mendapatkan kemoterapi seri 1.

\section{Simpulan}

Adaptasi di era pandemi terhadap penatalaksanaan kanker ginekologi perlu dilakukan sebagai upaya untuk meningkatkan survival outcome pada pasien baik dari segi operatif, kemoterapi, maupun radioterapi. Fokus dari penatalaksanaan kanker ginekologi saat ini tidak hanya pada penyakit ginekologi itu sendiri melainkan juga pengendalian terhadap risiko infeksi COVID-19 untuk meningkatkan manfaat survival dan menurunkan mortalitas serta morbiditas pasien

\section{Conflict Of Interest}

Tidak terdapat konflik kepentingan dalam penulisan artikel ini.

\section{Saran dan Ucapan Terimakasih (jika ada)}

Saran dan ucapan terimakasih bersifat 
optional (jika ada), ditulis satu paragraf

\section{Daftar Pustaka}

1. Komite Penanganan COVID-19 dan Pemulihan Ekonomi Nasional. Situasi virus COVID-19 di Indonesia. 2021.

2. $\mathrm{Wu} \mathrm{Z}$, McGoogan JM. Characteristics of and Important Lessons From the Coronavirus Disease 2019 (COVID-19) Outbreak in China: Summary of a Report of 72314 Cases From the Chinese Center for Disease Control and Prevention. JAMA. 2020 Apr;323(13):1239-42.

3. Huang C, Wang Y, Li X, Ren L, Zhao J, $\mathrm{Hu} \mathrm{Y}$, et al. Clinical features of patients infected with 2019 novel coronavirus in Wuhan, China. Lancet (London, England). 2020 Feb;395(10223):497506.

4. Akladios $\mathrm{C}$, Azais $\mathrm{H}$, Ballester $\mathrm{M}$, Bendifallah S, Bolze P-A, Bourdel N, et al. Recommendations for the surgical management of gynecological cancers during the COVID-19 pandemicFRANCOGYN group for the CNGOF. J Gynecol Obstet Hum Reprod. 2020;49(6):101729.

5. Anthony C, Ezugwu FO, Lawani OL. Challenges associated with the management of gynecological cancers in a tertiary hospital in South East Nigeria. Int J Womens Health. 2014;6:123-30.

6. Artha BP. Kanker Ginekologi dalam Masa Pandemi COVID-19. RSUP dr. Soeradji Tirtonegoro. 2020.

7. Pothuri B, Alvarez A, Armstrong DK, Chan J, Fader AN, Huh W, et al. Gynecologic Oncology Anti-cancer therapy and clinical trial considerations for gynecologic oncology patients during the COVID-19 pandemic crisis is. Gynecol Oncol. 2020;(xxxx).

8. Elledge $\mathrm{CR}$, Beriwal S, Chargari C, Chopra S, Erickson BA, Gaffney DK, et al. Gynecologic Oncology Radiation therapy for gynecologic malignancies during the COVID-19 pandemic : International expert consensus recommendations. Gynecol Oncol. 2020;

9. Ramirez PT, Chiva L, Eriksson AGZ, Frumovitz M, Fagotti A, Martin AG, et al. COVID-19 global pandemic: options for management of gynecologic cancers. BMJ Specialist Journals; 2020.

10. Fader AN, Huh WK, Kesterson J, Pothuri $\mathrm{B}$, Wethington S, Wright JD, et al. When to operate, hesitate and reintegrate: society of gynecologic oncology surgical considerations during the COVID-19 pandemic. Gynecol Oncol. 2020;158(2):236-43. 